\title{
Synthesis, Characterization and Solid State Molecular Structures of Five- and Six-Coordinate Primary Amide Manganese Porphyrin Complexes
}

\author{
Nan $\mathrm{Xu}^{\mathrm{a}}$, Alexander W. Bevak ${ }^{\mathrm{a}}$, Bernadette R. Armstrong ${ }^{\mathrm{a}}$, Douglas R. Powell ${ }^{\mathrm{b}}$ \\ ${ }^{a}$ Department of Chemistry, The Pennsylvania State University, Altoona College, 3000 Ivyside Park, \\ Altoona, Pennsylvania, U.S.A., 16601. Email: nxx103@psu.edu \\ ${ }^{b}$ Chemical Crystallography Laboratory, Department of Chemistry and Biochemistry, University of \\ Oklahoma, 101 Stephenson Parkway SLSRC, Norman, Oklahoma, U.S.A., 73019.
}

8

(C) 2016. This manuscript version is made available under the Elsevier user license http://www.elsevier.com/open-access/userlicense/1.0/ 


\section{Introduction}

Primary amides are a class of organic compounds, containing the $-\mathrm{C}(=\mathrm{O}) \mathrm{NH}_{2}$ functional group. Acrylamide is one of the simplest primary amides, and is the building block for polyacrylamide used in the manufacturing of plastics and polymers. Acrylamide formation in the human diet can result from high temperature food treatments.[1] The oxidation of asparagine by hydrogen peroxide also produces acrylamide at physiological conditions in vitro.[2] It is known that acrylamide is neurotoxic, and potentially carcinogenic in humans.[3] Thus, the interactions of acrylamide with heme proteins have been studied intensively.[4-7] Interestingly, an acrylamide analog (A-778935) has been reported as a nitric oxide (NO) independent soluble guanylyl cyclase (sGC) activator.[8] The binding site of the acrylamide analog to sGC was proposed to be located away from the heme moiety; however a nitric oxide (NO)-like direct heme interaction can not be excluded.

Synthetic manganese porphyrin complexes have been prepared and studied as models for heme-containing proteins.[9-14] Fukuzumi and coworkers reported the formation of a primary amide adduct of manganese porphyrin complexes in solution.[15] A tertiary amide manganese porphyrin complex has been prepared and structurally characterized.[16] Curiously, no heme acrylamide model complex has been reported to date. Consequently, we are very interested in investigating the interactions of acrylamide with manganese porphyrin complexes, and obtaining structural information that would help inform our understanding of these species.

We have prepared and characterized both five- and six-coordinate acrylamide and acetamide manganese porphyrin complexes. The X-ray crystal structures of these complexes 
have been obtained and reveal the sole O-binding mode of the acetamide and acrylamide as

ligands. In addition, the electro-reduction of the acrylamide porphyrin adducts were studied. As far as we know, these compounds represent the first series of structurally characterized primary amide metalloporphyrin complexes.

\section{Experimental Section}

All reactions were performed under an atmosphere of prepurified nitrogen using standard Schlenk glassware and/or in a Mbraun Unilab Glovebox. Solutions for spectroscopic studies were also prepared under a nitrogen atmosphere. Solvents were distilled from appropriate drying agents under nitrogen just prior to use: $\mathrm{CH}_{2} \mathrm{Cl}_{2}\left(\mathrm{CaH}_{2}\right)$, hexane $\left(\mathrm{CaH}_{2}\right)$, and toluene $(\mathrm{Na})$.

\subsection{Chemicals and Instrumentation.}

Acetamide $\left(\mathrm{CH}_{3} \mathrm{C}(=\mathrm{O}) \mathrm{NH}_{2}, 99 \%\right)$ was purchased from Acros. Acrylamide $\left(\mathrm{CH}_{2} \mathrm{CHC}(=\mathrm{O}) \mathrm{NH}_{2},>98 \%\right)$ and silver perchlorate anhydrous $\left(\mathrm{AgClO}_{4}, 99.5 \%\right)$, were purchased from Alfa Aesar Company. All chemicals were used as received. [(TPP)Mn(THF) $\left.)_{2}\right] \mathrm{ClO}_{4},[(\mathrm{~T}(p-$ $\mathrm{Cl}) \mathrm{PP}) \mathrm{Mn}(\mathrm{THF})_{2} \mathrm{ClO}_{4}$, and (OEP) $\mathrm{Mn}\left(\mathrm{ClO}_{4}\right)$ were prepared using the published procedures.[17] Infrared spectra were recorded on a Nicolet iS10 FTIR spectrometer. Cyclic voltammetry was performed at room temperature using a Pine wavenow potentiostat voltammetric analyzer. A three-electrode system was used and consisted of a Pt working electrode ( $1 \mathrm{~mm}$ disk), a Pt wire counter electrode, and a $\mathrm{Ag} / \mathrm{AgCl}$ reference electrode. 


\subsection{Synthesis}

$\left[(\mathbf{T P P}) \mathbf{M n}\left(\mathbf{O}=\mathbf{C}\left(\mathbf{N H}_{2}\right) \mathbf{C H}=\mathbf{C H}_{2}\right)_{2}\right] \mathbf{C l O}_{4}(\mathbf{1})$ : To a toluene solution $(20 \mathrm{~mL})$ of $\left[(\mathrm{TPP}) \mathrm{Mn}(\mathrm{THF})_{2}\right] \mathrm{ClO}_{4}(25.1 \mathrm{mg}, 0.028 \mathrm{mmol})$ was added $\mathrm{CH}_{2}=\mathrm{CHCONH}_{2}(6.1 \mathrm{mg}, 0.086$ mmol). The mixture was stirred for $45 \mathrm{~min}$, during which time the color of the solution changed from brown-green to green. The solvent was reduced to $\sim 5 \mathrm{~mL}$ and hexane $(20 \mathrm{~mL})$ was added. The black precipitate formed was collected by filtration, washed with hexane $(2 \times 15 \mathrm{~mL})$, and dried in vacuo to give $\left[(\mathrm{TPP}) \mathrm{Mn}\left(\mathrm{O}=\mathrm{C}\left(\mathrm{NH}_{2}\right) \mathrm{CH}=\mathrm{CH}_{2}\right)_{2}\right] \mathrm{ClO}_{4}(16.5 \mathrm{mg}, 0.0186 \mathrm{mmol}, 66 \%$ isolated yield). Slow evaporation of a $\mathrm{CH}_{2} \mathrm{Cl}_{2} /$ hexanes (1:1 ratio; $\left.5 \mathrm{~mL}\right)$ solution of the product at room temperature gave suitable crystals for X-ray diffraction studies. Anal. Calcd for $\mathrm{C}_{50} \mathrm{H}_{38} \mathrm{O}_{6} \mathrm{~N}_{6} \mathrm{ClMn} \bullet 0.025 \mathrm{CH}_{2} \mathrm{Cl}_{2} \bullet 0.3 \mathrm{C}_{6} \mathrm{H}_{14}: \mathrm{C}, 66.34 ; \mathrm{H}, 4.65 ; \mathrm{N}, 8.96 ; \mathrm{Cl}, 3.97$. Found: C, 66.24; H, 4.41; N, 8.61; Cl, 4.08. IR ( $\left.\mathrm{KBr}, \mathrm{cm}^{-1}\right)$ : $v_{\mathrm{CO}} 1655 \mathrm{~m}$; also $\mathrm{v}_{\mathrm{ClO}_{4}} 1107 \mathrm{~s}, 1090 \mathrm{~s}, 1073 \mathrm{~s}, 625 \mathrm{~m}$.

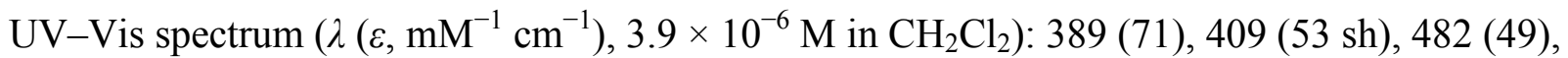
$571(15), 604(13) \mathrm{nm}$.

The other acetamide and acrylamide manganese porphyrin complexes were generated similarly using the respective porphyrin macrocycles and amides:

$\left[(\mathbf{T}(p-\mathbf{C l}) \mathbf{P P}) \mathrm{Mn}\left(\mathbf{O}=\mathbf{C}\left(\mathbf{N H}_{2}\right) \mathbf{C H}=\mathbf{C H}_{2}\right)_{2}\right] \mathbf{C l O}_{4}(2)$. Yield: $74 \%$. Anal. Calcd for $\mathrm{C}_{50} \mathrm{H}_{34} \mathrm{O}_{6} \mathrm{~N}_{6} \mathrm{Cl}_{5} \mathrm{Mn} \bullet 0.5 \mathrm{C}_{3} \mathrm{H}_{5} \mathrm{NO}$ : C, 57.14; H, 3.40; N, 8.41; Cl, 16.37. Found: C, 55.79; H, 3.43; N, 8.09; Cl, 16.00. IR (KBr, cm $\left.{ }^{-1}\right)$ : $v_{\mathrm{CO}} 1657 \mathrm{~s}$; also $\mathrm{v}_{\mathrm{ClO}_{4}} 1120 \mathrm{~s}, 1109 \mathrm{~s}, 1090 \mathrm{~m}, 1075 \mathrm{~s}, 623 \mathrm{~m}$. UV-Vis spectrum $\left(\lambda\left(\varepsilon, \mathrm{mM}^{-1} \mathrm{~cm}^{-1}\right), 3.4 \times 10^{-6} \mathrm{M}^{\text {in }} \mathrm{CH}_{2} \mathrm{Cl}_{2}\right): 389$ (57), 407 (44 sh), 482 (42), 569 (13), 603 (11) nm. Slow evaporation of a $\mathrm{CH}_{2} \mathrm{Cl}_{2} /$ hexane (1:1 ratio; $4 \mathrm{~mL}$ ) solution of the product at room temperature gave suitable crystals for X-ray diffraction studies. 
$\left[(\mathbf{O E P}) \mathbf{M n}\left(\mathbf{O}=\mathbf{C}\left(\mathbf{N H}_{2}\right) \mathbf{C H}=\mathbf{C H}_{2}\right)\right] \mathbf{C l O}_{4}(3)$. Yield: $72 \%$. Anal. Calcd for

$\mathrm{C}_{39} \mathrm{H}_{49} \mathrm{O}_{5} \mathrm{~N}_{5} \mathrm{ClMn} \bullet 0.4 \mathrm{C}_{3} \mathrm{H}_{5} \mathrm{NO}$ : C, 61.38; H, 6.53; N, 9.61; Cl, 4.51. Found: C, 61.16; H, 6.51;

$\mathrm{N}, 9.24 ; \mathrm{Cl}, 4.50 . \mathrm{IR}\left(\mathrm{KBr}, \mathrm{cm}^{-1}\right): \mathrm{v}_{\mathrm{CO}} 1655 \mathrm{~m}$; also $\mathrm{v}_{\mathrm{ClO}_{4}} 1107 \mathrm{~m}, 1109 \mathrm{~s}, 1056 \mathrm{~m}, 624 \mathrm{~m}$.

[(OEP) $\left.\mathbf{M n}\left(\mathbf{O}=\mathbf{C}\left(\mathbf{N H}_{2}\right) \mathbf{C H}_{3}\right)\right] \mathbf{C l O}_{4}(4)$. Yield: $80 \%$. Anal. Calcd for $\mathrm{C}_{38} \mathrm{H}_{49} \mathrm{O}_{5} \mathrm{~N}_{5} \mathrm{ClMn}$ : C, 61.16; H, 6.62; N, 9.39; Cl, 4.75. Found: C, 61.13; H, 6.78; N, 9.19; Cl, 4.95. IR (KBr, $\left.\mathrm{cm}^{-1}\right)$ : $v_{\mathrm{CO}} 1649 \mathrm{~m}$; also $\mathrm{v}_{\mathrm{ClO}_{4}} 1121 \mathrm{~m}, 1109 \mathrm{~s}, 1055 \mathrm{~m}, 624 \mathrm{~m}$. Slow evaporation of a $\mathrm{CH}_{2} \mathrm{Cl}_{2} /$ hexane (2:1 ratio; $4 \mathrm{~mL}$ ) solution of the product at room temperature gave suitable crystals for X-ray diffraction studies.

\subsection{Solid-State Structural Determinations.}

Details of crystal data and refinement are given in Table 1. Single-crystal X-ray diffraction data were collected using an instrument with a Bruker APEX ccd area detector and a graphite-monochromated Mo K $\alpha$ radiation $(\lambda=0.71073 \AA)$. The structures were solved by direct methods and refined by full-matrix least-squares methods on $F^{2}$.[18, 19]

(i) $\left[(\mathrm{TPP}) \mathrm{Mn}\left(\mathrm{O}=\mathrm{C}\left(\mathrm{NH}_{2}\right) \mathbf{C H}=\mathrm{CH}_{2}\right)_{2}\right] \mathrm{ClO}_{4}(\mathbf{1})$. Cell parameters were determined from a non-linear least squares fit of 9746 peaks in the range $2.17<\theta<27.49^{\circ}$. A total of 96675 data were measured in the range $1.589<\theta<27.508^{\circ}$ using $\varphi$ and $\omega$ oscillation frames. The data were merged to form a set of 10219 independent data with $\mathrm{R}(\mathrm{int})=0.0272$ and a coverage of $100.0 \%$. The monoclinic space group $P 2_{1} / n$ was determined by systematic absences and statistical tests and verified by subsequent refinement. Non-hydrogen atoms were refined with anisotropic displacement parameters. Hydrogen atom displacement parameters were set to 1.2 times the isotropic equivalent displacement parameters of the bonded atoms. A total of 713 parameters 
were refined against 519 restraints and 10219 data to give $\mathrm{wR}\left(F^{2}\right)=0.1377$ and $\mathrm{S}=0.996$ for weights of $\mathrm{w}=1 /\left[\sigma^{2}\left(F^{2}\right)+(0.0720 \mathrm{P})^{2}+6.7000 \mathrm{P}\right]$, where $\mathrm{P}=\left[F_{\mathrm{o}}^{2}+2 F_{\mathrm{c}}^{2}\right] / 3$. The final $\mathrm{R}(F)$ was 0.0476 for the 8950 observed, $[F>4 \sigma(F)]$, data. The largest shift/s.u. was 0.025 in the final refinement cycle. In the structure, one phenyl group and one acrylamide group were disordered. The occupancies of the phenyl atoms C33-C38 refined to 0.57(3) and 0.43(3) for the unprimed and primed atoms. The occupancies of atoms N6 and C48-C50 refined to 0.473(5), 0.392(5), and 0.133(3) for the unprimed, primed, and double-primed atoms. Restraints to make similar bonds approximately equivalent and to make displacement parameters of bonded atoms similar along the bonds were required.

(ii) $\left[(\mathbf{T}(p-\mathrm{Cl}) \mathbf{P P}) \mathrm{Mn}\left(\mathrm{O}=\mathrm{C}\left(\mathrm{NH}_{2}\right) \mathbf{C H}=\mathrm{CH}_{2}\right)_{2}\right] \mathrm{ClO}_{4}$ (2). Cell parameters were determined from a non-linear least squares fit of 9866 peaks in the range $2.36<\theta<27.51^{\circ}$. A total of 50864 data were measured in the range $1.894<\theta<27.535^{\circ}$ using $\phi$ and $\omega$ oscillation frames. The data were merged to form a set of 5417 independent data with $\mathrm{R}(\mathrm{int})=0.0210$ and a coverage of $100.0 \%$. The monoclinic space group $C 2 / c$ was determined by systematic absences and statistical tests and verified by subsequent refinement. Non-hydrogen atoms were refined with anisotropic displacement parameters. The positions of hydrogen atoms bonded to carbons were initially determined by geometry and were refined using a riding model. Hydrogen atom displacement parameters were set to 1.2 times the isotropic equivalent displacement parameters of the bonded atoms. A total of 337 parameters were refined against 21 restraints and 5417 data to give $w \mathrm{R}\left(F^{2}\right)=0.0934$ and $\mathrm{S}=0.855$ for weights of $\mathrm{w}=1 /\left[\sigma^{2}\left(F^{2}\right)+(0.0800 \mathrm{P})^{2}+4.4000 \mathrm{P}\right]$, where $\mathrm{P}=\left[F_{\mathrm{O}}^{2}+2 F_{\mathrm{c}}^{2}\right] / 3$. The final $\mathrm{R}(F)$ was 0.0268 for the 4999 observed, $[F>4 \sigma(F)]$, data. The largest shift/s.u. was 0.002 in the final 
refinement cycle. The perchlorate anion was located near to a 2-fold rotation axis. Restraints on the positional parameters of the anion atoms were required.

(iii) $\left[(\mathrm{OEP}) \mathrm{Mn}\left(\mathrm{O}=\mathrm{C}\left(\mathrm{NH}_{2}\right) \mathrm{CH}_{3}\right)\right] \mathrm{ClO}_{4} \cdot \mathrm{CH}_{2} \mathrm{Cl}_{2}\left(\mathbf{4} \cdot \mathrm{CH}_{2} \mathrm{Cl}_{2}\right)$. Cell parameters were determined from a non-linear least squares fit of 9975 peaks in the range $2.20<\theta<30.96^{\circ}$. A total of 58290 data were measured in the range $1.525<\theta<31.542^{\circ}$ using $\varphi$ and $\omega$ oscillation frames. The data were merged to form a set of 13512 independent data with $\mathrm{R}(\mathrm{int})=0.0291$ and a coverage of $100.0 \%$. The triclinic space group $\mathrm{P} \overline{1}$ was determined by statistical tests and verified by subsequent refinement. Non-hydrogen atoms were refined with anisotropic displacement parameters. The positions of hydrogens bonded to carbons were initially determined by geometry and were refined using a riding model. Hydrogen atom displacement parameters were set to 1.2 (1.5 for methyl) times the isotropic equivalent displacement parameters of the bonded atoms. A total of 484 parameters were refined against 13512 data to give $w \mathrm{R}\left(F^{2}\right)=0.1219$ and $\mathrm{S}=0.992$ for weights of $\mathrm{w}$ $=1 /\left[\sigma^{2}\left(F^{2}\right)+(0.0600 \mathrm{P})^{2}+1.5100 \mathrm{P}\right]$, where $\mathrm{P}=\left[F_{\mathrm{O}}{ }^{2}+2 F_{\mathrm{c}}{ }^{2}\right] / 3$. The final $\mathrm{R}(F)$ was 0.0434 for the 11012 observed, $[F>4 \sigma(F)]$, data. The largest shift/s.u. was 0.002 in the final refinement cycle. An additional dichloromethane was observed that was severely disordered and best modeled using the Squeeze method.[20]

The crystallographic data for the complexes are summarized in Table 1. 
Table 1. Crystal Data and Structure Refinement

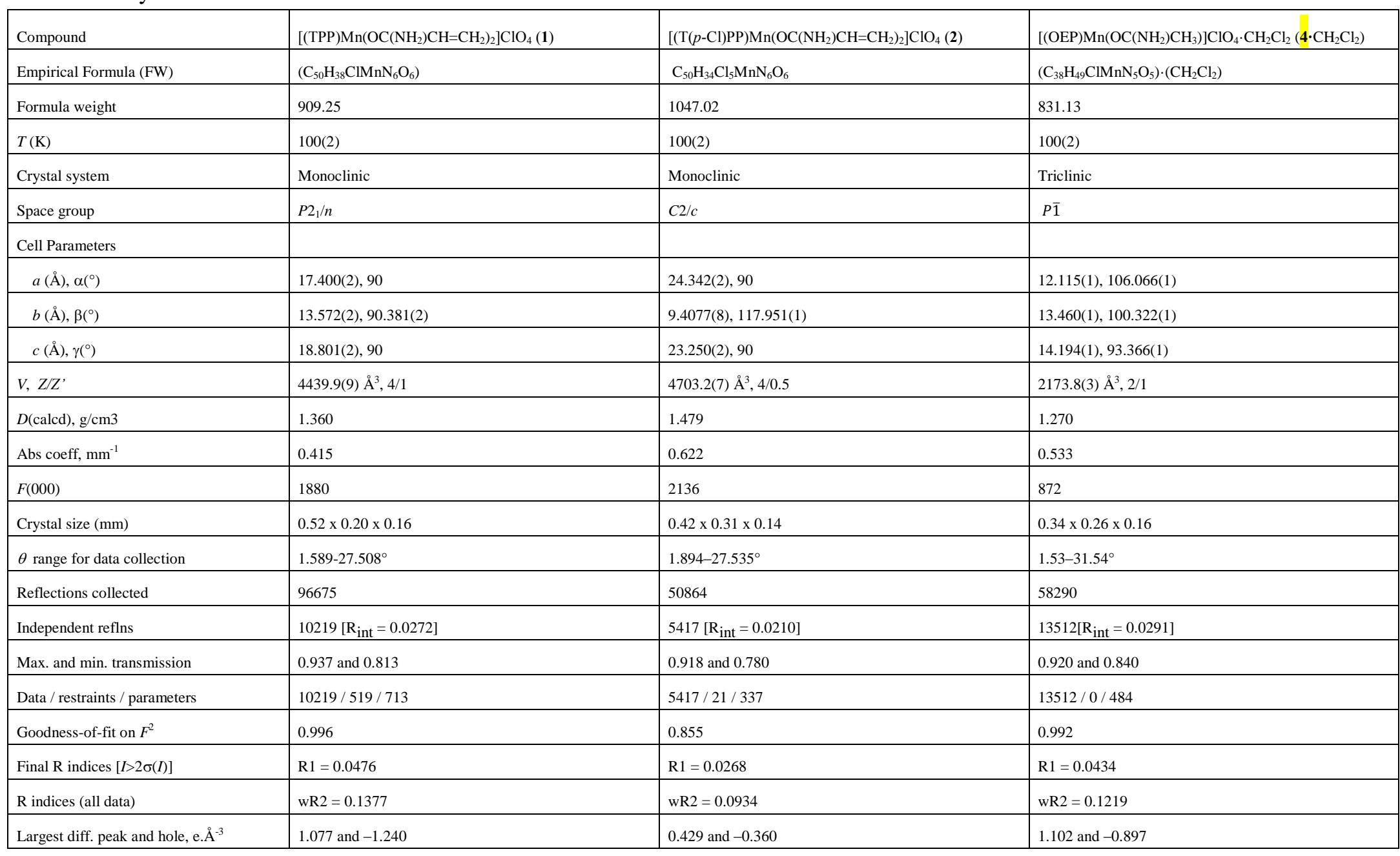




\section{Results and discussion}

\subsection{Synthesis and characterization}

The acrylamide manganese porphyrin complexes were prepared by displacing coordinated solvent or perchlorate from the precursors $\left[(\right.$ por $\left.) \mathrm{Mn}(\mathrm{THF})_{2}\right] \mathrm{ClO}_{4}($ por $=\mathrm{TPP}, \mathrm{T}(p-$ $\mathrm{Cl}) \mathrm{PP})$ and $(\mathrm{OEP}) \mathrm{Mn}\left(\mathrm{ClO}_{4}\right)$. The reactions of the tetraphenylporphyrin $\left[(\right.$ por $\left.) \mathrm{Mn}(\mathrm{THF})_{2}\right] \mathrm{ClO}_{4}$ compounds with excess acrylamide in toluene generated, after workup, the six-coordinate acrylamide derivatives, $\left[(\right.$ por $\left.) \mathrm{Mn}\left(\mathrm{O}=\mathrm{C}\left(\mathrm{NH}_{2}\right) \mathrm{CH}=\mathrm{CH}_{2}\right)_{2}\right] \mathrm{ClO}_{4}$ in $66 \%(\mathrm{TPP})$ and $74 \%(\mathrm{~T}(p$ $\mathrm{Cl}$ )PP) isolated yields. The five-coordinate acrylamide and acetamide manganese octaethylporphyrin complexes, $\left[(\mathrm{OEP}) \mathrm{Mn}\left(\mathrm{O}=\mathrm{C}\left(\mathrm{NH}_{2}\right) \mathrm{R}\right)\right] \mathrm{ClO}_{4}\left(\mathrm{R}=\mathrm{CH}_{3}, \mathrm{CH}=\mathrm{CH}_{2}\right)$, were prepared in a similar manner, using $\mathrm{CH}_{2} \mathrm{Cl}_{2}$ as the solvent instead of toluene. We find that the primary amide ligands are only weakly bound, as they dissociate readily from the manganese center at low concentration. Thus, the use of excess amides in the reactions and recrystallizations is required to assure the binding of the amides to the manganese centers. These products are moderately air-stable in the solid sate. No decomposition was observed in the solid state in air for one week based on IR spectroscopy. The extended exposure to halogenated solvents such as dichloromethane leads to the formation of five-coordinate (por) $\mathrm{MnCl}$ due to the great affinity of Mn to halogens.[16]

The IR spectra of the six-coordinate acrylamide $\left[(\mathrm{TPP}) \mathrm{Mn}\left(\mathrm{O}=\mathrm{C}\left(\mathrm{NH}_{2}\right) \mathrm{CH}=\mathrm{CH}_{2}\right)_{2}\right] \mathrm{ClO}_{4}$ and $\left[(\mathrm{T}(p-\mathrm{Cl}) \mathrm{PP}) \mathrm{Mn}\left(\mathrm{O}=\mathrm{C}\left(\mathrm{NH}_{2}\right) \mathrm{CH}=\mathrm{CH}_{2}\right)_{2}\right] \mathrm{ClO}_{4}$ complexes as $\mathrm{KBr}$ pellets show intense bands at $1655 \mathrm{~cm}^{-1}$ and $1657 \mathrm{~cm}^{-1}$, respectively, that we assign to the $v_{\mathrm{CO}} \mathrm{S}$ for the coordinatedacrylamide. The five-coordinate $\left[(\mathrm{OEP}) \mathrm{Mn}\left(\mathrm{O}=\mathrm{C}\left(\mathrm{NH}_{2}\right) \mathrm{CH}=\mathrm{CH}_{2}\right)\right] \mathrm{ClO}_{4}$ and $\left[(\mathrm{OEP}) \mathrm{Mn}\left(\mathrm{O}=\mathrm{C}\left(\mathrm{NH}_{2}\right) \mathrm{CH}_{3}\right)\right] \mathrm{ClO}_{4}$ complexes show the $\mathrm{v}_{\mathrm{CO}}$ bands at $1655 \mathrm{~cm}^{-1}$ and $1649 \mathrm{~cm}^{-1}$, respectively. The $v_{\mathrm{CO}} \mathrm{S}$ of the bound acetamide and acrylamide ligands are lower than those of 
free acetamide $\left(1695 \mathrm{~cm}^{-1}\right)[21]$ and acrylamide $\left(1681 \mathrm{~cm}^{-1}\right)[21]$ which suggests an $(\mathrm{C}=) \mathrm{O}$ binding mode. We note that lowered $v_{\mathrm{CO}}$ of the O-bound acetamides and acrylamides have been reported for their metal complexes.[22-24] In addition, the IR absorption bands centered at $\sim 1100$ (br) and $\sim 622 \mathrm{~cm}^{-1}$ indicate the presence of uncoordinated perchlorate anion in the complexes.[25] The UV-vis spectra of the two tetraphenyl-based porphyrins were obtained in the presence of $\sim 50 \times$ excess of acrylamide in $\mathrm{CH}_{2} \mathrm{Cl}_{2}$. The resulting spectra resemble the characteristic absorption bands of high-spin six-coordinate Mn(III) porphyrin complexes.[16, 26]

\subsection{Crystallography}

The six-coordinate bis-acrylamide complexes: We were successful in obtaining X-ray diffraction quality crystals of two bis-acrylamide complexes from their $\mathrm{CH}_{2} \mathrm{Cl}_{2} /$ hexane solutions. The corresponding crystal structures of these two compounds [(TPP) Mn $\left.\left(\mathrm{O}=\mathrm{C}\left(\mathrm{NH}_{2}\right) \mathrm{CH}=\mathrm{CH}_{2}\right)_{2}\right]-$ $\mathrm{ClO}_{4}(\mathbf{1})$, and $\left[(\mathrm{T}(p-\mathrm{Cl}) \mathrm{PP}) \mathrm{Mn}\left(\mathrm{O}=\mathrm{C}\left(\mathrm{NH}_{2}\right) \mathrm{CH}=\mathrm{CH}_{2}\right)_{2}\right] \mathrm{ClO}_{4}(\mathbf{2})$ are shown in Figures 1 and 2, respectively, and selected bond lengths and angles are listed in Table 2.

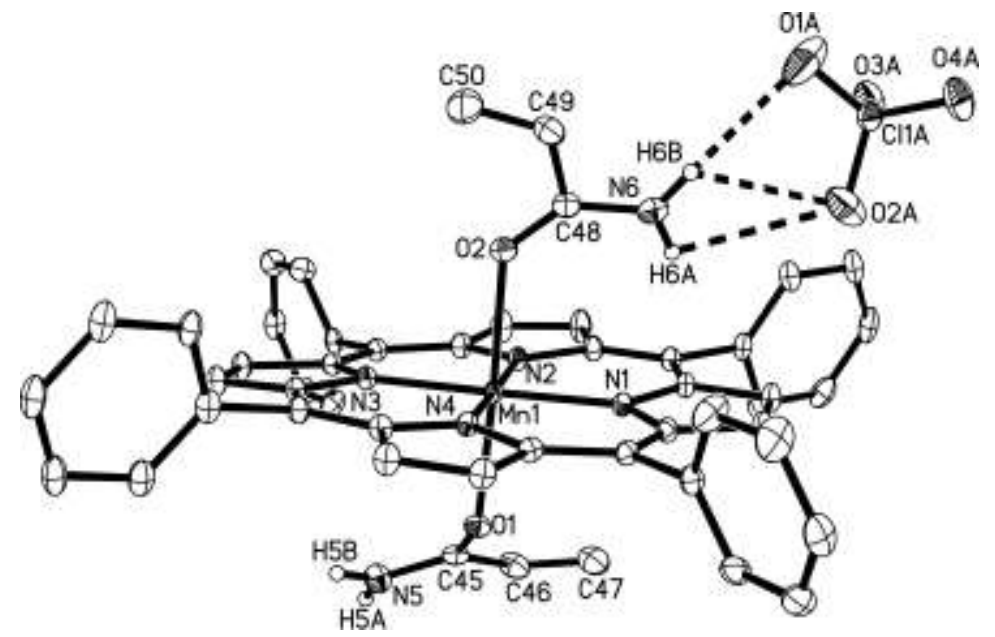

Figure 1. Structure of the bis-acrylamide complex $\left[(\mathrm{TPP}) \mathrm{Mn}\left(\mathrm{O}=\mathrm{C}\left(\mathrm{NH}_{2}\right) \mathrm{CH}=\mathrm{CH}_{2}\right)_{2}\right] \mathrm{ClO}_{4}(\mathbf{1})$. Hydrogen atoms on carbon atoms have been omitted for clarity. 


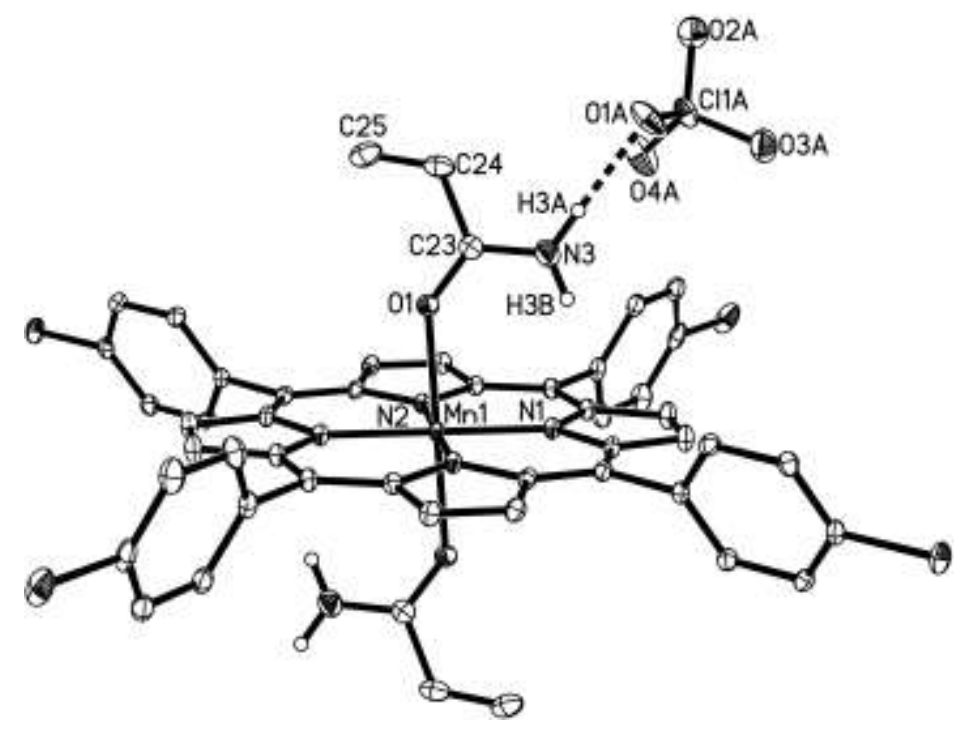

Figure 2. Structure of the bis-acrylamide complex $\left[(\mathrm{T}(p-\mathrm{Cl}) \mathrm{PP}) \mathrm{Mn}\left(\mathrm{O}=\mathrm{C}\left(\mathrm{NH}_{2}\right) \mathrm{CH}=\mathrm{CH}_{2}\right)_{2}\right] \mathrm{ClO}_{4}(\mathbf{2})$. Hydrogen atoms on carbon atoms have been omitted for clarity.

As shown in Figs. 1 and 2, each of the molecular structures contains only one porphyrin cation and one associated perchlorate anion, that is weakly $\mathrm{H}$-bonded to the $\mathrm{NH}_{2}$ group of the acrylamide ligands with the $\mathrm{O} \cdots \mathrm{N}$ distances of $2.949 \AA(\mathrm{O} 2 \mathrm{~A})$ and $3.177 \AA(\mathrm{O} 1 \mathrm{~A})$ in 1 and $\AA$ in 2, respectively. The acrylamide ligands are O-bound to the manganese centers in the two complexes, which is consistent with the lower $v_{\mathrm{CO}}$ of the bound acrylamide. The equatorial Mn$\mathrm{N}$ (por) lengths in the two complexes are in the 2.013(2) $\AA-2.018(1) \AA$ range. The axial Mn-O bonds are 2.184(1) $\AA$ and 2.280(2) $\AA$ for 1, and 2.212(1) $\AA$ for 2 . The similar bond lengths and resulting tetragonal elongation geometry around the Mn center have been observed in other highspin $\mathrm{d}^{4}$ six-coordinate $\mathrm{Mn}$ (III) porphyrin complexes.[16, 26, 27] It is worth noting that most of the $\mathrm{d}^{4} \mathrm{Mn}(\mathrm{III})$ porphyrin complexes reported have a high-spin $\mathrm{Mn}(\mathrm{III})$ ion, with only a couple of exceptions.[28, 29] 
Table 2. Selected Bond Lengths ( $\AA$ ) and Angles (deg) for the Primary Amide Manganese Porphyrin Compounds and Free Acetamide and Acrylamide.

\begin{tabular}{|c|c|c|c|c|c|c|}
\hline Compounds & $\mathrm{Mn}-\mathrm{O}$ & $\mathrm{C}-\mathrm{O}$ & $\mathrm{C}-\mathrm{N}\left(\mathrm{H}_{2}\right)$ & $\mathrm{Mn}-\mathrm{N}($ por $)$ & $\mathrm{C}=\mathrm{C}$ & $\angle \mathrm{Mn}-\mathrm{O}-\mathrm{C}$ \\
\hline \multirow[t]{4}{*}[(\mathrm{TPP})\mathrm{Mn}(\mathrm{O}=\mathrm{C}(\mathrm{NH}_{2})\mathrm{CH}=\mathrm{CH}_{2})_{2}]{$\mathrm{ClO}_{4}(\mathbf{1})$} & $2.1841(14)$ & $1.253(2)$ & $1.328(3)$ & $2.013(2)$ & $1.317(3)$ & $131.08(13)$ \\
\hline & $2.280(2)$ & $1.239(3)$ & $1.321(3)$ & 2.013(2) & $1.313(4)$ & $132.1(2)$ \\
\hline & & $1.240(4)^{*}$ & $1.327(4)^{*}$ & $2.014(2)$ & $1.315(4)^{*}$ & $135.0(2)^{*}$ \\
\hline & & $1.254(3)^{*}$ & $1.321(4)^{*}$ & $2.016(2)$ & $1.316(5)^{*}$ & $120.9(5)^{*}$ \\
\hline \multirow[t]{2}{*}[(\mathrm{T}(p-\mathrm{Cl})\mathrm{PP})\mathrm{Mn}(\mathrm{O}=\mathrm{C}(\mathrm{NH}_{2})\mathrm{CH}=\mathrm{CH}_{2})_{2}]{$\mathrm{ClO}_{4}(\mathbf{2})$} & $2.2115(9)$ & $1.244(2)$ & $1.327(2)$ & $2.0178(10)$ & $1.320(2)$ & $139.60(9)$ \\
\hline & & & & $2.0180(10)$ & & \\
\hline \multirow[t]{4}{*}[(\mathrm{OEP})\mathrm{Mn}(\mathrm{O}=\mathrm{C}(\mathrm{NH}_{2})\mathrm{CH}_{3})]{$\mathrm{ClO}_{4}(\mathbf{4})$} & $2.0925(11)$ & $1.249(2)$ & $1.322(2)$ & $2.0085(13)$ & & $142.07(11)$ \\
\hline & & & & $2.0079(13)$ & & \\
\hline & & & & $2.0099(13)$ & & \\
\hline & & & & $2.0104(13)$ & & \\
\hline $\mathrm{CH}_{3} \mathrm{C}(=\mathrm{O}) \mathrm{NH}_{2}[30]$ & & $1.242(2)$ & $1.326(2)$ & & & \\
\hline $\mathrm{CH}=\mathrm{CH}_{2} \mathrm{C}(=\mathrm{O}) \mathrm{NH}_{2}[31]$ & & $1.2413(14)$ & $1.3275(14)$ & & $1.3106(18)$ & \\
\hline
\end{tabular}

* The disordered components

The bound acrylamide ligands in $\mathbf{1}$ and $\mathbf{2}$ show nearly planar geometry. Comparing to the $\mathrm{C}-\mathrm{O}$ bond length of 1.241(1) $\AA$ in free acrylamide[31], one of the acrylamide ligands in $\mathbf{1}$ shows a longer $\mathrm{C}-\mathrm{O}$ bond at $1.253(2) \AA$. The other acrylamide ligand displays a three-fold disorder with the major component having a C-O bond length of $1.239(3) \AA$, and the two minor components having the C-O bond lengths of 1.240(4) $\AA$ and $1.254(3) \AA$. The $\mathrm{C}-\mathrm{NH}_{2}$ and C-C bonds are in the $1.321(4) \AA$ to $1.328(3) \AA$, and 1.313 (4) $\AA$ to $1.320(2) \AA$ ranges, respectively, which are comparable to those of free acrylamide. The molecular structure of complex $\mathbf{2}$ shows similar bond lengths of $\mathrm{C}-\mathrm{O}(1.244(2) \AA)$ and $\mathrm{C}-\mathrm{NH}_{2}(1.327(2) \AA$ ) with those of free acrylamide, and a slightly longer C-C bond (1.320(2) Å).

The five-coordinate complex: A five-coordinate ionic iron porphyrin complex, $\left[(\mathrm{OEP}) \mathrm{Fe}\left(\mathrm{ONNMe}_{2}\right)\right] \mathrm{ClO}_{4}$, has been crystallized by taking advantage of the $\pi$ - $\pi$ porphyrin stacking in OEP-type compounds, where a 5-coordinate monomer essentially blocks the 6th 
coordination site.[32] We adopted the same strategy to obtain the five-coordinate manganese acrylamide complex. However, attempts to obtain single crystals of the $\left[(\mathrm{OEP}) \mathrm{Mn}\left(\mathrm{O}=\mathrm{C}\left(\mathrm{NH}_{2}\right) \mathrm{CH}=\mathrm{CH}_{2}\right)\right]^{+}$product were not successful. We then employed another primary amide, acetamide, and we were able to obtain single crystals of the five-coordinate acetamide manganese porphyrin complex, namely $\left[(\mathrm{OEP}) \mathrm{Mn}\left(\mathrm{O}=\mathrm{C}\left(\mathrm{NH}_{2}\right) \mathrm{CH}_{3}\right)\right] \mathrm{ClO}_{4}$ from its $\mathrm{CH}_{2} \mathrm{Cl}_{2}$ /hexane solution. As shown in Figure 3, the structure contains a single acetamide ligand bound to manganese porphyrin cation. The perchlorate anion is H-bounded to the acetamide $\mathrm{NH}_{2}$ group through its oxygen atoms with the O1A $\cdots \mathrm{N} 5$ distance of $2.933 \AA$.

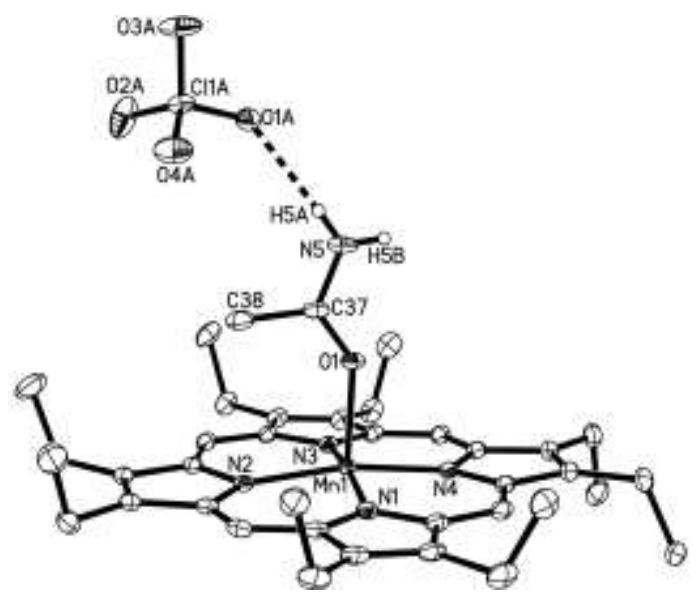

Figure 3. Structure of the acetamide complex $\left[(\mathrm{OEP}) \mathrm{Mn}\left(\mathrm{O}=\mathrm{C}\left(\mathrm{NH}_{2}\right) \mathrm{CH}_{3}\right)\right] \mathrm{ClO}_{4}(4)$. Hydrogen atoms on carbon atoms have been omitted for clarity.

For the acetamide complex $\left[(\mathrm{OEP}) \mathrm{Mn}\left(\mathrm{O}=\mathrm{C}\left(\mathrm{NH}_{2}\right) \mathrm{CH}_{3}\right)\right] \mathrm{ClO}_{4}(\mathbf{4})$, the equatorial $\mathrm{Mn}-$ N(por) and axial Mn-O bond lengths are 2.008(1)-2.010(1) $\AA$ and 2.093(1) $\AA$, respectively. The manganese is displaced $0.19 \AA$ out of the 24 -atom plane towards the acetamide ligand in this five-coordinated complex. The $\mathrm{C}-\mathrm{O}$ bond and $\mathrm{C}-\mathrm{N}$ bond of the bound acetamide are 1.249(2) $\AA$ and 1.322(2) A, respectively, which are comparable to those of other O-bound acetamide Ni[33], $\mathrm{Pt}[34]$ complexes and free acetamide[30]. 
The $\pi-\pi$ interactions between the two adjacent OEP macrocycles is most likely responsible for the formation of stable five-coordinate complexes during the crystallization.[32] As shown in Figure 4, for $\left[(\mathrm{OEP}) \mathrm{Mn}\left(\mathrm{O}=\mathrm{C}\left(\mathrm{NH}_{2}\right) \mathrm{CH}_{3}\right)\right] \mathrm{ClO}_{4}$, the mean plane separation (M.P.S.) between the 24 -atom porphyrin planes is $3.37 \AA$, the $\mathrm{Mn}$ - Mn distance is $4.752 \AA$, and the lateral shift is $\sim 2.91 \AA$. These structural parameters suggest that this compound is in between Class S and Class I with real $\pi-\pi$ interactions between the two neighbor macrocycles, according to the nomenclature of Scheidt and Lee[35].

(a)
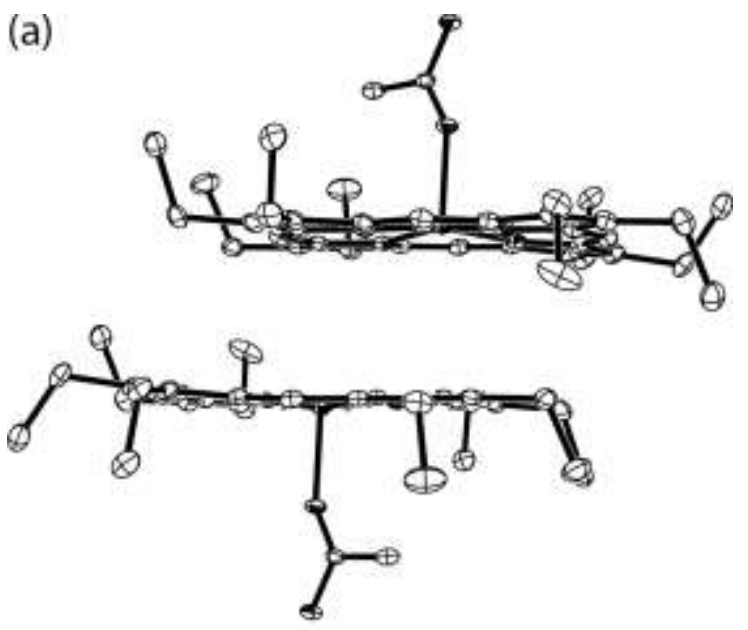

(b)

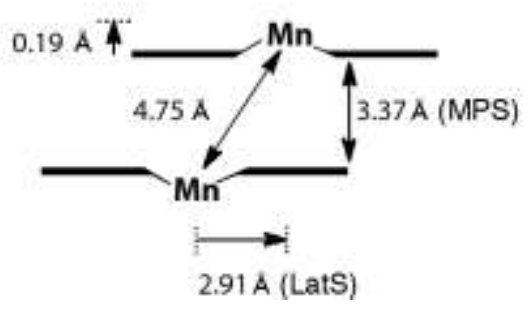

Figure 4. (a)View of the $\pi$ - $\pi$ stacking involving the cation of $\left[(\mathrm{OEP}) \mathrm{Mn}\left(\mathrm{O}=\mathrm{C}\left(\mathrm{NH}_{2}\right) \mathrm{CH}_{3}\right)\right] \mathrm{ClO}_{4}(4)$, showing (top) the $3.37 \AA$ separation of the porphyrin planes, and (b) Sketch of the geometric parameters for the OEP-OEP $\pi$ stacking in $\left[(\mathrm{OEP}) \mathrm{Mn}\left(\mathrm{O}=\mathrm{C}\left(\mathrm{NH}_{2}\right) \mathrm{CH}_{3}\right)\right] \mathrm{ClO}_{4}$. Perchlorate anions and hydrogen atoms have been omitted for clarity. 


\subsection{Electro-reduction}

The electrochemistry studies of many synthetic manganese porphyrins have been reported.[11, 36-38] In this work, the reductions of the $\left[(\mathrm{T}(p-\mathrm{Cl}) \mathrm{PP}) \mathrm{Mn}\left(\mathrm{O}=\mathrm{C}\left(\mathrm{NH}_{2}\right) \mathrm{CH}=\mathrm{CH}_{3}\right)_{2}\right]^{+}$ and $\left[(\mathrm{TPP}) \mathrm{Mn}\left(\mathrm{O}=\mathrm{C}\left(\mathrm{NH}_{2}\right) \mathrm{CH}=\mathrm{CH}_{3}\right)_{2}\right]^{+}$cations were examined in the presence of $\sim 50 \times$ excess of acrylamide in $\mathrm{CH}_{2} \mathrm{Cl}_{2}$ at room temperature. The excess acrylamide was added to ensure the formation of the six-coordination acrylamide $\mathrm{Mn}^{\mathrm{III}}$ porphyrin complexes. The resulting cyclic voltammograms are shown in Figure 5.

(a)
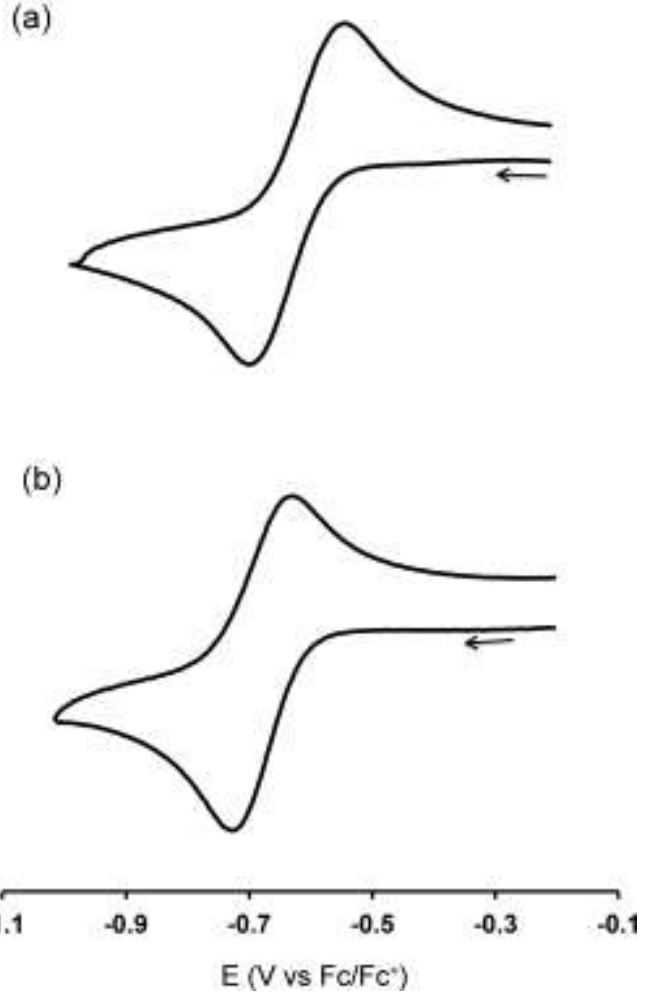

Figure 5. Cyclic voltammograms showing the first reductions of $\left[(\mathrm{T}(p-\mathrm{Cl}) \mathrm{PP}) \mathrm{Mn}\left(\mathrm{O}=\mathrm{C}\left(\mathrm{NH}_{2}\right) \mathrm{CH}=\mathrm{CH}_{2}\right)_{2}\right]^{+}$ (a) and $\left[(\mathrm{TPP}) \mathrm{Mn}\left(\mathrm{O}=\mathrm{C}\left(\mathrm{NH}_{2}\right) \mathrm{CH}=\mathrm{CH}_{2}\right)_{2}\right]^{+}$(b) in the presence of $\sim 50 \times$ excess acrylamide, in $\mathrm{CH}_{2} \mathrm{Cl}_{2}$ containing $0.1 \mathrm{M} \mathrm{NBu}_{4} \mathrm{PF}_{6}$ and at a scan rate of $200 \mathrm{mV} / \mathrm{s}$.

Both cations show well-defined reversible reduction couples. The TPP derivative is reduced at an $\mathrm{E}_{1 / 2}$ of $-0.68 \mathrm{~V}$ versus $\mathrm{Fc} / \mathrm{Fc}^{+}$within the solvent potential limit, which is more negative than the reduction potential of $-0.63 \mathrm{~V}$ for $\mathrm{T}(p-\mathrm{Cl}) \mathrm{PP}$ derivative. The potential difference between the two cations is consistent with the electron-withdrawing ability of the 
corresponding porphyrin macrocycles. The reduction potentials of a series of similar sixcoordinate $\mathrm{Mn}(\mathrm{III})$ perchlorate complexes were reported, ranging from $-0.09 \mathrm{~V}$ to $-0.25 \mathrm{~V}$ versus SCE in various solvents.[37] A similar bis-DMF manganese porphyrin complex, $\left[(\mathrm{TPP}) \mathrm{Mn}(\mathrm{DMF})_{2}\right] \mathrm{ClO}_{4}$, showed the first reduction potential at $-0.19 \mathrm{~V}$ versus SCE in DMF, which is $-0.65 \mathrm{~V}$ using $\mathrm{Fc} / \mathrm{Fc}^{+}$as the reference $\left(\mathrm{E}^{\mathrm{o}^{\prime}} \mathrm{Fc}_{\mathrm{Fc}}{ }^{+}=+0.47 \mathrm{~V}\right.$ versus $\left.\mathrm{SCE}[39]\right)$. The first reduction of these $\mathrm{Mn}$ (III) porphyrin complexes is metal centered, reducing $\mathrm{Mn}$ (III) to $\mathrm{Mn}$ (II). Upon the reduction, one axial ligand would dissociate from the manganese center to form a five coordinate manganese porphyrin complex.[37, 40,41] Based on the similar reduction behavior observed in our work, it is most likely that the Mn(III) centers of both TPP and T( $p-\mathrm{Cl}) \mathrm{PP}$ derivatives are reduced to $\mathrm{Mn}(\mathrm{II})$ and one of the two axial acrylamide ligands dissociates from the metal center to form a five-coordinate $\mathrm{Mn}(\mathrm{II})$ complex upon the first reduction as shown in eq. 1 .

$$
\begin{gathered}
{\left[(\text { por }) \mathrm{Mn}^{\mathrm{III}}\left(\mathrm{O}=\mathrm{C}\left(\mathrm{NH}_{2}\right) \mathrm{CH}=\mathrm{CH}_{2}\right)_{2}\right]^{+}+\mathrm{e}^{-} \rightleftharpoons\left[(\text { por }) \mathrm{Mn}^{\mathrm{II}}\left(\mathrm{O}=\mathrm{C}\left(\mathrm{NH}_{2}\right) \mathrm{CH}=\mathrm{CH}_{2}\right)\right]+\mathrm{O}=\mathrm{C}\left(\mathrm{NH}_{2}\right) \mathrm{CH}=\mathrm{CH}_{2}} \\
(\text { por }=\mathrm{TPP}, \mathrm{T}(p-\mathrm{Cl}) \mathrm{PP})
\end{gathered}
$$

The dissociate acrylamide molecule can reversibly bind back to the manganese center while it is oxidized back to $\mathrm{Mn}(\mathrm{III})$.

\section{Conclusions}

We have prepared a number of primary amide manganese porphyrins from the reactions of the cationic $[(\mathrm{OEP}) \mathrm{Mn}] \mathrm{ClO}_{4}$ and $\left[(\right.$ por $\left.) \mathrm{Mn}(\mathrm{THF})_{2}\right] \mathrm{ClO}_{4}$ precursors with acrylamide or acetamide. We have structurally characterized, by single-crystal X-ray crystallography, two sixcoordinate $\left[(\right.$ por $\left.) \mathrm{Mn}\left(\mathrm{O}=\mathrm{C}\left(\mathrm{NH}_{2}\right) \mathrm{CH}=\mathrm{CH}_{2}\right)_{2}\right] \mathrm{ClO}_{4}($ por $=\mathrm{TPP}, \mathrm{T}(p-\mathrm{Cl}) \mathrm{PP})$ compounds and one five-coordinate $\left[(\mathrm{OEP}) \mathrm{Mn}\left(\mathrm{O}=\mathrm{C}\left(\mathrm{NH}_{2}\right) \mathrm{CH}_{3}\right)\right] \mathrm{ClO}_{4}$ derivative. We have shown that the $\mathrm{C}=\mathrm{O}$ vibrations of the amides shift negatively upon the coordination. Importantly, a sole $\mathrm{O}$ binding 
mode of the amide ligands has been shown in the crystal structures. Furthermore, the electroreductions of the two six-coordinate acrylamide complexes have been studied. The redox behavior is consistent with those for other manganese porphyrins that show metal-centered reduction. This class of compounds represents the first reported molecular structure of primary amide metalloporphyrin complexes.

Appendix A. Supplementary data: CCDC 1504199-1504201 contains the supplementary crystallographic data for 1,2 and 4 . These data can be obtained free of charge via www.ccdc.cam.ac.uk/conts/retrieving.html, or from the Cambridge Crystallographic Data

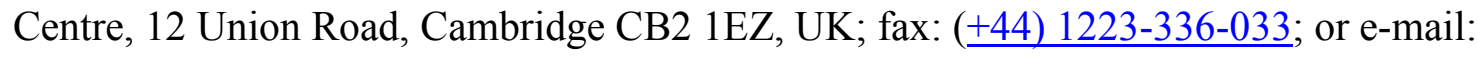
deposit@ccdc.cam.ac.uk.

\section{Acknowledgments}

We are grateful for the financial support from Penn State Altoona Research Development Grant for this work. We also thank the National Science Foundation (CHE-0130835) and the University of Oklahoma for funds to purchase the diffractometer. 


\section{References}

[1] E. Tareke, P. Rydberg, P. Karlsson, S. Eriksson, M. Tornqvist, J. Agr. Food. Chem., 50 (2002) 4998-5006.

[2] E. Tareke, T.M. Heinze, G.G. da Costa, S. Ali, J. Agr. Food Chem., 57 (2009) 9730-9733.

[3] M. Friedman, J. Agr. Food Chem., 51 (2003) 4504-4526.

[4] S.C.J. Sumner, T.R. Fennell, T.A. Moore, B. Chanas, F. Gonzalez, B.I. Ghanayem, Chem. Res. Toxicol., 12 (1999) 1110-1116.

[5] O. Doroshyenko, U. Fuhr, D. Kunz, D. Frank, M. Kinzig, A. Jetter, Y. Reith, A. Lazar, D. Taubert, J. Kirchheiner, M. Baum, G. Eisenbrand, F.I. Berger, D. Bertow, A. Berkessel, F. Sorgel, E. Schomig, D. Tomalik-Scharte, Cancer Epidemiol. Biomarkers. Prev., 18 (2009) 433-443.

[6] E. Bergmark, C.J. Calleman, L.G. Costa, Toxicol. Appl. Pharm., 111 (1991) 352-363.

[7] E. Bergmark, C.J. Calleman, F.S. He, L.G. Costa, Toxicol. Appl. Pharm., 120 (1993) 45-54.

[8] M. Nakane, T. Kolasa, R.J. Chang, L.N. Miller, R.B. Moreland, J.D. Brioni, J. Pharmacol. Sci., 102 (2006) 231-238.

[9] W.Y. Lu, J.F. Bartoli, P. Battioni, D. Mansuy, New J. Chem., 16 (1992) 621-628.

[10] H. Hori, M. Ikedasaito, T. Yonetani, Biochim. Biophys. Acta., 912 (1987) 74-81.

[11] Z.N. Zahran, M.J. Shaw, M.A. Khan, G.B. Richter-Addo, Inorg. Chem., 45 (2006) 26612668.

[12] Z.N. Zahran, J. Lee, S.S. Alguindigue, M.A. Khan, G.B. Richter-Addo, Dalton Trans., (2004) 44-50.

[13] R.B. VanAtta, C.E. Strouse, L.K. Hanson, J.S. Valentine, J. Am. Chem. Soc., 109 (1987) 1425-1434.

[14] B.R.S. Lemos, D. CarvalhoDa-Silva, D.Z. Mussi, L.D. Santos, M.M. da Silva, M.E.M.D. de Carvalho, J.S. Reboucas, Y.M. Idemori, Appl. Catal. a-Gen, 400 (2011) 111-116.

[15] S. Fukuzumi, Y. Kondo, S. Mochizuki, T. Tanaka, J. Chem. Soc. Perk. Trans. II, (1989) 1753-1761.

[16] C.L. Hill, M.M. Williamson, Inorg. Chem., 24 (1985) 2836-2841.

[17] S.J. Fox, L. Chen, M.A. Khan, G.B. Richter-Addo, Inorg. Chem., 36 (1997) 6465-6467.

[18] G.M. Sheldrick, Acta Crystallogr. C, 71 (2015) 3-8.

[19] G.M. Sheldrick, Acta Crystallogr. A, 71 (2015) 3-8.

[20] A.L. Spek, Acta Crystallogr. C, 71 (2015) 9-18.

[21] J. Neville, J. Mol. Spectrosc., 6 (1961) 205-214.

[22] K.B. Girma, V. Lorenz, S. Blaurock, F.T. Edelmann, Z. Anorg. Allg. Chem., 631 (2005) 2763-2769.

[23] K.B. Girma, V. Lorenz, S. Blaurock, F.T. Edelmann, Inorg. Chim. Acta, 359 (2006) 364368.

[24] J.L. Du, S.J. Rettig, R.C. Thompson, J. Trotter, P. Betz, A. Bino, Can. J. Chem., 70 (1992) 732-741.

[25] N.M.N. Gowda, S.B. Naikar, G.K.N. Reddy, Adv. Inorg. Chem., 28 (1984) 255-299.

[26] R.B. Brown, M.M. Williamson, C.L. Hill, Inorg. Chem., 26 (1987) 1602-1608.

[27] C.L. Hill, M.M. Williamson, Inorg. Chem., 24 (1985) 3024-3030.

[28] J.T. Landrum, K. Hatano, W.R. Scheidt, C.A. Reed, J. Am. Chem. Soc., 102 (1980) 67296735.

[29] L. Galich, H. Huckstadt, H. Homborg, J. Porphyr. Phthalocya., 2 (1998) 79-87. 
[30] J.W. Bats, M.C. Haberecht, M. Wagner, Acta Crystallogr. E, 59 (2003) O1483-O1485.

[31] Q.L. Zhou, Z.H. Zhang, Z.L. Jing, Acta Crystallogr. E, 63 (2007) O3039-U3433.

[32] N. Xu, L.E. Goodrich, N. Lehnert, D.R. Powell, G.B. Richter-Addo, Inorg. Chem., 49 (2010) 4405-4419.

[33] M.E. Stone, Robertso.Be, E. Stanley, J. Chem. Soc. A, (1971) 3632-3636.

[34] R. Cini, F.P. Intini, L. Maresca, C. Pacifico, G. Natile, Eur. J. Inorg. Chem., (1998) 13051312.

[35] W.R. Scheidt, Y.J. Lee, Struct. Bonding, 64 (1987) 1-70.

[36] H.K. Lee, Y.K. Choi, K.H. Chung, S. Jeon, B. Kor. Chem. Soc., 18 (1997) 549-552.

[37] S.L. Kelly, K.M. Kadish, Inorg. Chem., 21 (1982) 3631-3639.

[38] G.M. Ucoski, S. Nakagaki, F.S. Nunes, J. Porphyr. Phthalocya., 18 (2014) 1093-1100.

[39] N.G. Connelly, W.E. Geiger, Chem. Rev., 96 (1996) 877-910.

[40] X.H. Mu, F.A. Schultz, Inorg. Chem., 31 (1992) 3351-3357.

[41] K. Lawson, J. Gross, P.W. Crawford, Helv. Chim. Acta, 87 (2004) 120-132. 